\title{
Transient Fluorescence Labeling: Low Affinity-High Benefits
}

\author{
Maxim M. Perfilov (1), Alexey S. Gavrikov (D), Konstantin A. Lukyanov (i) and Alexander S. Mishin *(D) \\ Shemyakin-Ovchinnikov Institute of Bioorganic Chemistry, Russian Academy of Sciences, \\ 117997 Moscow, Russia; sufrep@gmail.com (M.M.P.); gavrikovalexey1@gmail.com (A.S.G.); kluk@ibch.ru (K.A.L.) \\ * Correspondence: mishin@ibch.ru
}

Citation: Perfilov, M.M.; Gavrikov, A.S.; Lukyanov, K.A.; Mishin, A.S. Transient Fluorescence Labeling: Low Affinity-High Benefits. Int. J. Mol. Sci. 2021, 22, 11799. https://doi.org/ $10.3390 /$ ijms222111799

Academic Editor: Phillip E. Klebba

Received: 16 September 2021

Accepted: 28 October 2021

Published: 30 October 2021

Publisher's Note: MDPI stays neutral with regard to jurisdictional claims in published maps and institutional affiliations.

Copyright: (C) 2021 by the authors. Licensee MDPI, Basel, Switzerland. This article is an open access article distributed under the terms and conditions of the Creative Commons Attribution (CC BY) license (https:// creativecommons.org/licenses/by/ $4.0 /)$.

\begin{abstract}
Fluorescent labeling is an established method for visualizing cellular structures and dynamics. The fundamental diffraction limit in image resolution was recently bypassed with the development of super-resolution microscopy. Notably, both localization microscopy and stimulated emission depletion (STED) microscopy impose tight restrictions on the physico-chemical properties of labels. One of them - the requirement for high photostability — can be satisfied by transiently interacting labels: a constant supply of transient labels from a medium replenishes the loss in the signal caused by photobleaching. Moreover, exchangeable tags are less likely to hinder the intrinsic dynamics and cellular functions of labeled molecules. Low-affinity labels may be used both for fixed and living cells in a range of nanoscopy modalities. Nevertheless, the design of optimal labeling and imaging protocols with these novel tags remains tricky. In this review, we highlight the pros and cons of a wide variety of transiently interacting labels. We further discuss the state of the art and future perspectives of low-affinity labeling methods.
\end{abstract}

Keywords: super-resolution microscopy; PAINT; fluorescent labeling; exchangeable labels

\section{Introduction}

Most fluorescent labeling methods are based on the permanent-high-affinity or covalent-attachment of dyes to the target molecules. For example, immunofluorescence techniques [1] employ fluorescently labeled antibodies to directly or indirectly stain proteins or other antigens. Another popular approach is the introduction of a genetically encoded tag into the structure of the target protein. Such fusion proteins should be expressed in the cells of interest in culture or in vivo. Green fluorescent protein (GFP) and homologous fluorescent proteins (FPs) represent self-sufficient tags, which develop fluorescence on their own shortly after protein synthesis due to the formation of a fluorophore inside the FP barrel [2]. There are also other classes of fluorescent proteins that fluoresce due to the binding of endogenous cofactors such as flavins or biliverdin [3]. These tags are convenient but have a limited color palette. Finally, a diverse set of exogenously applied chemical dyes can be permanently attached to the protein of interest fused with specially designed genetically encoded enzymatic tags, such as SNAP-tag and HaloTag (reviewed in [4]).

Still, every method of permanent labeling has its own limitations. For example, antibodies-derived labels are highly specific to target structure [5,6] and allow using various organic dyes conjugated with antibodies. However, their field of application is usually limited to fixed cells. Furthermore, their sheer size ( $>10 \mathrm{~nm}$ [7]) may increase the apparent dimensions of a labeled structure, especially in the case of a combination of primary and secondary antibodies [7]. In multitarget imaging, the use of multiple antibodies could lead to spatial interference between the antibodies and mislocalization of targets [8]. Ultimately, the size of antibodies limits the effective labeling density [8].

Another covalent labeling technique is genetically fusing fluorescent proteins [9]. Labeling with FPs remains at present the method of choice for live-cell microscopy of intracellular protein targets, although some FPs could be effectively used in fixed cells as well [10]. With the smaller size of the FP-tags, higher sampling density can be achieved, 
in comparison with antibody-based labeling. Indeed, the sizes of an actin subunit and fluorescent proteins are close $(\approx 6[11]$ and $\approx 5 \mathrm{~nm}[12]$ in max projection, respectively), which in theory makes it possible to label each monomer. However, in practice, cells express their own unlabeled actin, which also incorporates into a microfilament, thus diluting the stained monomers and ultimately lowering the labeling density [13]. It is curious that despite its relatively small size, FP-fusion nevertheless is bulky enough to perturb the functionality of the target proteins [14]. In addition, fluorescent proteins are strongly susceptible to damage caused by light irradiation. This process is called photobleaching, and it significantly reduces the span of time available for continuous imaging with FP [15]. Susceptibility to photobleaching, incomplete photoconversion [16], and incomplete maturation make fluorescent proteins less-than-optimal for some types of super-resolution microscopy [7].

Finally, labeling is possible by organic dyes, conjugated with small molecules responsible for homing to target structures such as fluorescently labeled phalloidin for actin staining [17] or 4,4-difluoro-4-bora-3a,4a-diaza-s-indacene (BODIPY) for membrane staining [18]. Additionally, silicon-rhodamine conjugates SiR-actin (with desbromo-desmethyljasplakinolide) and SiR-tubulin (with docetaxel) stain actin filaments and microtubules, respectively [19]. Although these probes demonstrate bright and photostable labeling in various types of microscopies, both in vitro and in vivo, they slightly affect the polymerization and functionality of actin or tubulin, making the interpretation of live-cell imaging with these dyes more complicated $[19,20]$.

The effective alternative to labels with high affinity to target could be low-affinity tags (with $\mathrm{K}_{\mathrm{D}}$ in the micromolar range). Kiuchi et al., demonstrated that exchangeable probes provide high labeling density [8]. In addition, the labeling becomes more photostable [21] and less toxic and disruptive to the functioning of cellular structures [14,22]. The basic advantages of exchangeable probes over high-affinity-based ones are presented in Figure 1.

A

\section{Permanent labeling}

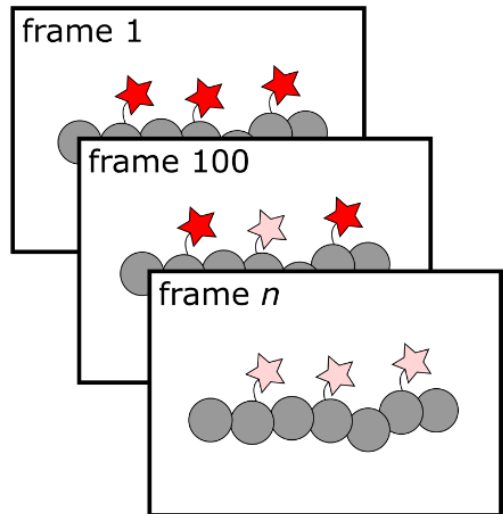

B

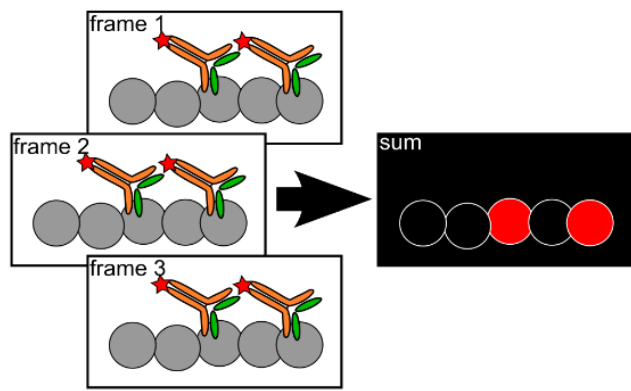

\section{Exchangeable labeling}
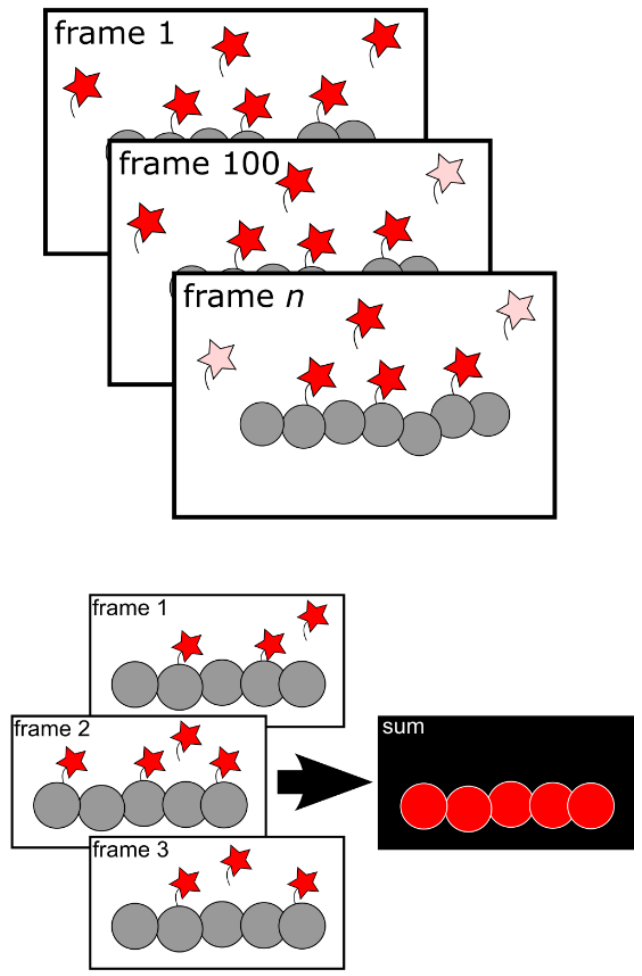

Figure 1. Cont. 

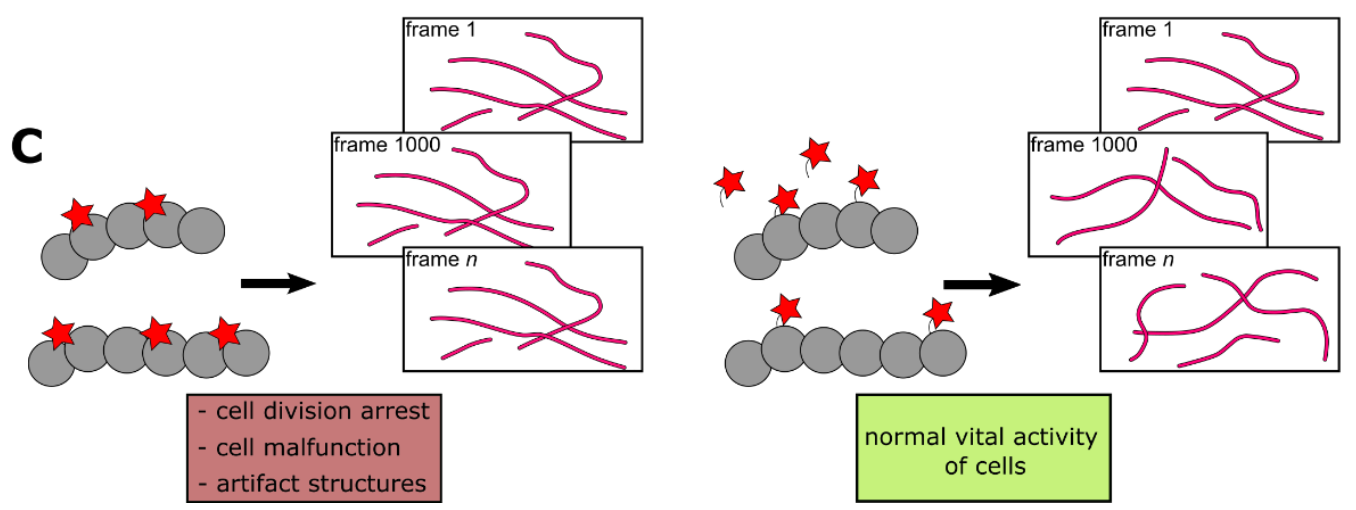

Figure 1. Comparison of permanent (high-affinity or covalent) and exchangeable (transient) labeling. (A) Permanent labels are constantly exposed to light irradiation and inevitably photobleached. Therefore, the fluorescent signal deteriorates, making prolonged imaging more complicated. In contrast, the continuous exchange of low-affinity labels with undamaged ones from cytosol or medium increases the apparent photostability of labeling. Red stars denote fluorescent labels, pink stars denote photobleached labels. (B) High-affinity labels already bound to target structures, due to their large size, can sterically interfere with the binding of other label molecules. Alternatively, frame-by-frame accumulation of low-affinity labels' positions followed by frames merging increases effective labeling density. (C) Bulky labels, continuously bound to target structures, may affect the dynamics and functioning of the latter. In addition, some labels, such as fluorescently labeled taxol or fluorescent proteins could drastically disturb cell activity. However, in the case of low-affinity labeling, target molecules remain untagged most of the time and therefore their functioning is less hindered.

Low-affinity labeling is a diverse group that includes such methods as PAINT (point accumulation for imaging in nanoscale topography) for membrane imaging, fluorogenactivating proteins, and exchangeable organic dyes of a narrow specificity. Therefore, it could be challenging to choose a suitable method for each particular experiment. In an attempt to make this task easier, herein, we consider and compare low-affinity labeling techniques, highlight the general principles underlying such techniques, and suggest future directions of development.

\section{PAINTing the Cell}

A large family of methods utilizing exchangeable probes shares 'PAINT' in their names. Prerequisites for the development of PAINT were developed in the work of Mei et al. [23]. The authors used the fluorogenic property of the Nile Red probe: in the hydrophobic environment, it exhibits a much higher quantum yield than in the hydrophilic one [24]. This feature allowed observing the probe only at the moment of interaction with target hydrophobic vesicles. In this seminal work, an unusual technique, trajectory time distribution optical microscopy (TTDOM) was used, so instead of measuring the intensity of light, the statistics of probe-target collisions were determined. TTDOM allowed for highresolution imaging [25], but it required complex and hard-to-reach equipment, preventing the mass adoption of this technique.

In contrast, the PAINT method could be implemented with a standard microscopy gear [26]. With the very same Nile Red probe, Sharonov and Hochstrasser demonstrated precise imaging of large unilamellar vesicles. In essence, PAINT is continuous imaging of the sample, in the presence of a mobile fluorescent probe, which constantly binds and unbinds the target structure. Binding events result in bursts of fluorescence, followed by unbinding of probes and loss of signal. Importantly, the probe concentration controls the collision rate and labeling density. The recommended density of about one molecule per $\mu \mathrm{m}^{2}$ ensures that fluorescent burst corresponds to point spread function (PSF) from a single molecule, allowing for precise localization. Another essential set of parameters is the on-time $\boldsymbol{\tau}_{\mathrm{on}}$ of fluorescent burst (or "bound" time $\boldsymbol{\tau}_{\mathrm{b}}$ ) and the time between collisions $\boldsymbol{\tau}_{\text {off }}$ (or "dissociated" time $\boldsymbol{\tau}_{\mathrm{d}}$ ). For better results, the time between frames should not exceed the former, and the latter should be longer than the exposure time of the frame. 
The compliance with the specified conditions enables frame-by-frame determination of fluorophore coordinates, which could be summed to the final reconstructed image, similar to other localization microscopy implementations (Figure 2A) [27-29].

A

PAINT
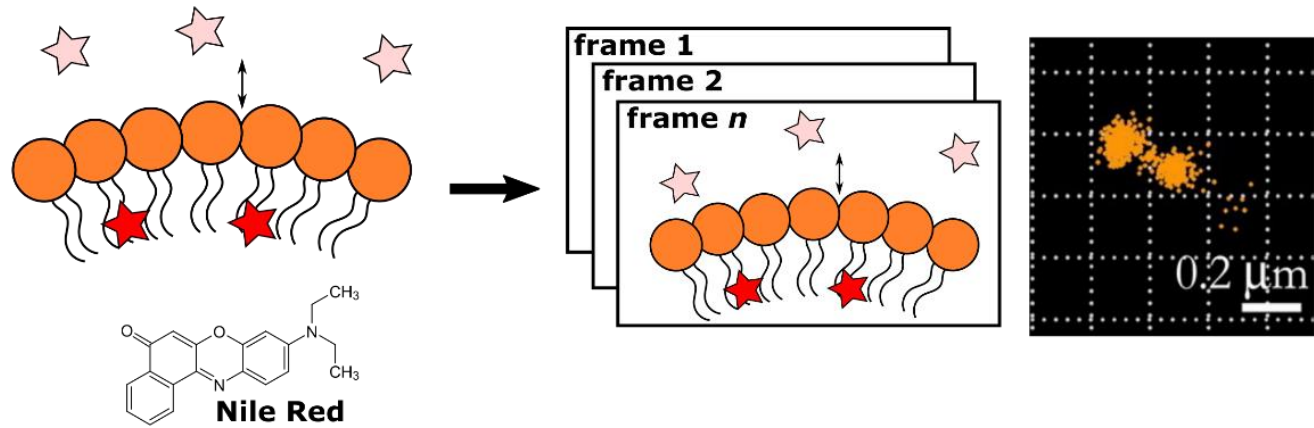

B

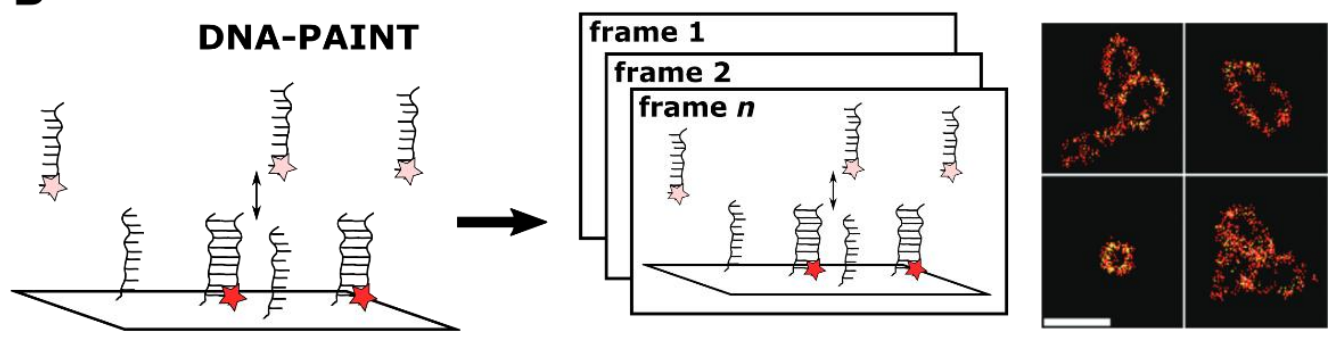

C

UPAINT
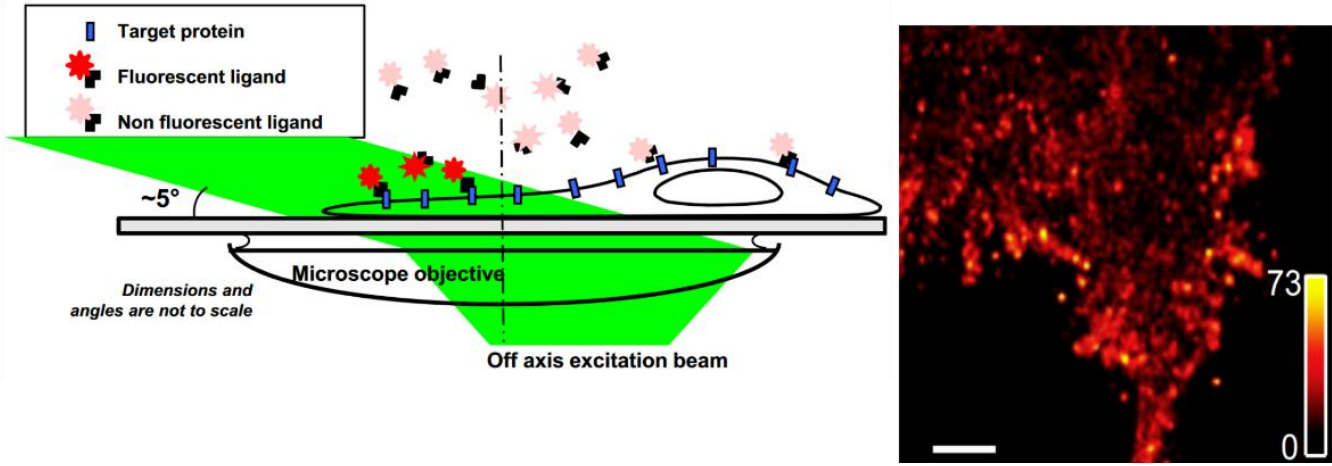

Figure 2. A schematic illustration of PAINT methods. (A) An original PAINT approach. Left: an environment-sensitive probe (Nile Red) fluorescently bursts upon reversible interaction with the lipid layer. Center: accumulation of fluorescent bursts during $n$ frames registration. Right: the reconstructed image of vesicles, imaged with PAINT approach using Nile Red probe. Reprinted from Sharonov et al. [26] (copyright (2006) National Academy of Sciences). (B) A DNA-PAINT approach. Left: in the DNA-PAINT labeling system target and dye molecules are conjugated to complementary DNA strands. Transient interaction between strands temporarily co-localizes fluorescent probes with a target structure. This binding event is detected as a burst of fluorescence. Center: accumulation of fluorescent bursts during $n$ frames registration. Right: reconstructed images of long rectangular DNA-origami oligomers labeled with DNA-PAINT. Scale bar $500 \mathrm{~nm}$. Reprinted with permission from Jungmann et al. [30]. Copyright (2010) American Chemical Society. (C) A uPAINT approach. Left: fluorescent probes bind to target sites in the cell. A low-angle excitation laser beam (angle of about $5^{\circ}$ ) illuminates $\approx 2 \mu \mathrm{m}$ thick cross section, thereby excites predominantly only bound labels. Right: Super-resolved image of the transmembrane protein TM-6His labeled with trisNTA-AT647N obtained by uPAINT. Scale bar $1 \mu \mathrm{m}$. Reprinted from Giannone et al. [31], copyright (2010), with permission from Elsevier. 
Later, with the invention of DNA-PAINT [30], the PAINT principle was applied for the labeling of nucleic acids and proteins. The central imaging principle was borrowed from single-molecule speckle microscopy: only immobilized probes give rise to discrete fluorescent signals, while unbound probes remain undetectable [32]. In DNA-PAINT, the DNA-origami structures [33] with docking strands ("docking") imaged with 7-9 nt long oligonucleotide strands conjugated with dyes ("imager") [30]. The transient interaction between the "docking" and the "imager" was followed by a fluorescent burst lasting for $\boldsymbol{\tau}_{\mathrm{b}}$, while the dissociation caused a lowering of the fluorescent signal for $\boldsymbol{\tau}_{\mathrm{d}}$ (Figure 2B). Moreover, the length of the imager's strand could be additionally tuned to achieve the optimal combination of $\boldsymbol{\tau}_{\mathrm{b}}$ and $\boldsymbol{\tau}_{\mathrm{d}}$. The combination of specific exchanging labels and TIRF (total internal reflection fluorescence) microscopy, which reduces the out-of-focus signal from unbound dyes, provided a reasonable signal-to-noise ratio of images. In addition to imaging, DNA-PAINT was used in the qualitative characterization of DNA-origami structures $[34,35]$.

In turn, protein imaging required additional adapters between DNA strands and target proteins, such as antibodies [34] or aptamers [36]. Based on DNA-PAINT with antibodies, several approaches were developed. Among them were the method for the quantification of target molecules (qPAINT [34]) and Exchange-PAINT for multitarget imaging using orthogonal pairs of strands $[37,38]$. A DNA-PAINT variant tPAINT was used for live-cell dynamic tension imaging [39], with the help of an additional stem-loop structure included within the complex of interacting DNA molecules, designed to expose a cryptic docking site under external force.

One more implementation of DNA-PAINT combined it with yet another method for improving the resolution-super-resolution optical fluctuation imaging (SOFI) [40]. In SOFI, the reconstruction of super-resolved images is based on the analysis of temporal fluorescence fluctuation of fluorophores. Although the SOFI was presented as a fast method for contrast-enhanced and background-reduced imaging [40], today STORM (stochastic optical reconstruction microscopy) and PALM (photoactivated localization microscopy) methods could be used for high temporal resolution imaging [21,41] with much better spatial resolution of reconstructed images [42].

Thus, the remaining benefits of SOFI are in the absence of specific requirements for labels such as photo-switching, and the tolerance of the method for densely labeled targets $[40,43]$. Still, the usability of dyes and fluorescent proteins is fundamentally limited by their photobleaching. To overcome this limitation, Glogger et al., combined SOFI with the DNA-PAINT method [44]. As a result, a high concentration of imager strand compared to original DNA-PAINT [30] generated sufficient target-specific fluctuations and allowed an increase in both contrast and resolution.

It is worth considering separately the uPAINT approach: an exception from transient labeling in the PAINT family. The "uPAINT" stands for "universal PAINT" due to its usability for various biomembrane molecules with specific ligands conjugated with fluorophores [31]. The authors used low-angle (or grazing angle) epi-illumination to filter out unbound probes, allowing the excitation of relatively thin layers (Figure 2C) [45]. However, unlike other PAINT methods, uPAINT does not require exchangeable labels.

Finally, it is possible to image RNA molecules in a PAINT-like manner. RNA staining with non-covalent binding of fluorogenic dyes, pioneered in Spinach aptamer [46], have developed to a mature and extensive toolset (reviewed in [47]). One recent example, RhoBAST (rhodamine-binding aptamer for super-resolution imaging techniques) [48], utilizes the main ideas of original PAINT - transient interactions and fluorescence activation upon probe-target binding. Like DNA-PAINT methods, RhoBAST exploits ligand exchange, but with much faster kinetics.

\section{Fluorogen-Activating Proteins (Protein-PAINT)}

In another approach to transient labeling, developed in parallel with DNA-PAINT, a specially designed protein reversibly binds a small molecule of fluorogen, activating 
(turning "ON") its fluorescence. Within the protein-fluorogen complex, the fluorescence of the fluorogen can be enhanced mainly by limiting the conformational mobility, the difference in the polarity of the amino acid microenvironment within the binding pocket, or binding-induced changes of the protonation state. In the literature, the proteins in these protein-fluorogen complexes are dubbed fluorogen-activating proteins (FAPs).

In one of the first works in the field of protein-fluorogen interactions, a molecule from the class of so-called fluorescent molecular rotors was used, which binds to polymerized tubulin in vitro, resulting in limitation of fluorogen rotational relaxation and fluorescence enhancement [49]. Another research group obtained monoclonal antibodies specific to a fluorescent molecular rotor, resulting in a more than $40 \mathrm{x}$ fold increase in fluorescence quantum yield [50]. While the principle of non-covalent binding of fluorogen and its exchangeability has not yet been exploited in this work, the manuscript underpins the much later antibody-based labeling system.

In 2008, Szent-Gyorgyi et al., isolated human single-chain antibodies (scFv) specific to thiazole orange and malachite green derivatives (Figure 3) and used them to visualize cell surface and secretory apparatus [51]. This labeling system based on the binding of fluorogens to antibodies developed rapidly. A broad palette of antibody variants and fluorogenic dyes appeared, covering almost the entire visible spectrum from blue to near-infrared [52,53]. The use of such antibodies has recently been expanded: a photosensitizer [54], a pH sensor [55], and the so-called affibodies [56-58] were created. The affinity of most of these complexes of fluorogenic dyes with antibodies is relatively strong and lies in the low nanomolar range [51]. This labeling system can also be used for single-molecule localization microscopy (SMLM) both in living and fixed cells, showing good reconstruction quality and localization density during acquisition [17].
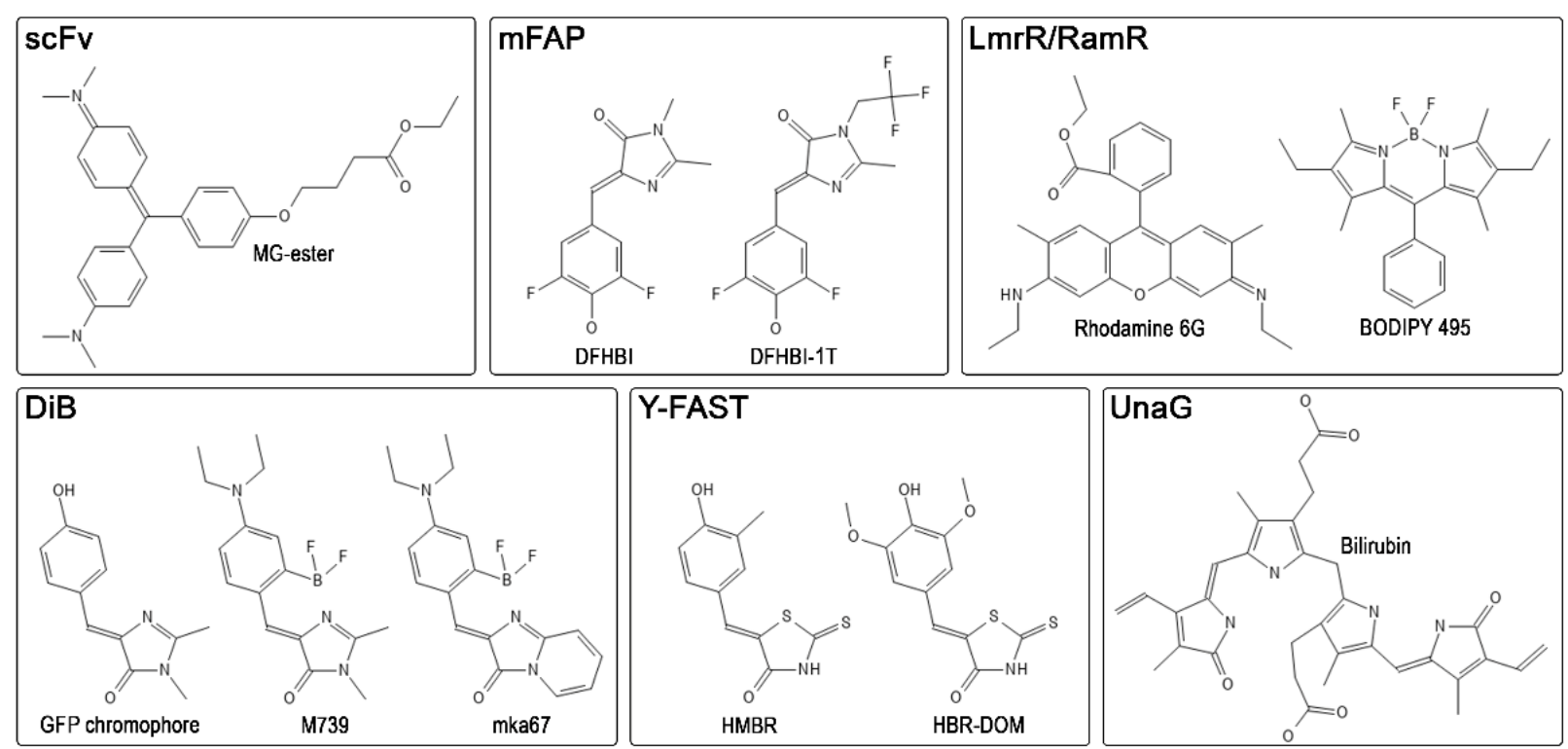

Figure 3. Common representatives of ligands for known FAP-based labeling systems. MG-ester-malachite green ester, DFHBI-difluoro-4-hydroxybenzylidene imidazolinone, DFHBI-1T-3,5-difluoro-4-hydroxybenzylidene-2,2,2-trifluoroethyl imidazolinone, BODIPY -4,4-difluoro-4-bora-3a,4a-diaza-s-indacene, HMBR-4-hydroxy-3-methylbenzylidene rhodanine, HBR-DOM-4-hydroxy-3,5-dimethoxybenzylidene rhodanine.

Yet another representative of fluorogen-activating proteins is the UnaG protein, which reversibly binds the endogenous ligand bilirubin (Figure 3) and activates its fluorescence [59]. This protein was found to be responsible for the fluorescence of the skeletal muscles of the Japanese eel $[59,60]$. UnaG localizes mainly in the small-diameter muscle fibers of eels. This protein is smaller than conventional fluorescent proteins, about $15.6 \mathrm{kDa}$, and binds bilirubin tightly $\left(\mathrm{K}_{\mathrm{D}}=98 \mathrm{pM}\right)$. However, the bilirubin-UnaG complex can be 
photo-switched to a non-fluorescent state through bilirubin's interaction with oxygen. Due to the non-covalent binding of bilirubin with UnaG, oxidized bilirubin detaches from the protein, freeing up the binding site for another bilirubin molecule [61]. The kinetics of this process is easily controlled by the illumination intensity and the concentration of the ligand. The exact dissociation constant for oxidized bilirubin remains unknown. Nevertheless, UnaG has been successfully used in single-molecule localization microscopy [61].

Later, a yellow fluorescence-activating and absorption-shifting tag (Y-FAST) was developed [62]. Fluorogen-activating protein FAST, which is almost two times smaller than conventional fluorescent proteins $(\approx 14 \mathrm{kDa})$, was obtained by directed evolution of bacterial photoactive yellow protein PYP. A unique feature of the FAST system is a high signal-to-background ratio, caused by the bathochromic shift of the excitation spectra of the fluorogen within the protein complex due to its deprotonation upon binding. The first fluorogen developed for FAST was 4-hydroxy-3-methylbenzylidene rhodanine (HMBR), which resembles the GFP chromophore. In a complex with Y-FAST, the excitation peak of HMBR (Figure 3) is shifted to $481 \mathrm{~nm}$ with the emission peak at $540 \mathrm{~nm}$. In contrast, unbound HMBR remains fully protonated in the physiological range of $\mathrm{pH}$. Despite low affinity $\left(\mathrm{K}_{\mathrm{D}} \approx 130 \mathrm{nM}\right.$, corresponding to the residence time in the complex of $160 \mathrm{~ms}$ at $25^{\circ} \mathrm{C}$ ) [62], a high signal-to-background ratio allows for successful labeling of target cellular proteins. Y-FAST quickly started to develop, and a set of useful chemical-genetic tools based on FAST protein appeared. For example, the iFAST mutant and its tandem variant td-iFAST with improved brightness and many red fluorogens were created [63]. The variety of colors and exchangeability of fluorogens made it possible to perform multicolor dynamic labeling of proteins in living cells by alternately washing and adding fluorogens [64-67]. Since then, a split system based on FAST has appeared [68], as well as orthogonal reporters greenFAST and redFAST [69], and new, improved FAST mutants with novel fluorogens [70]. Recently, following NMR analysis of the FAST-fluorogen complex, a shortened nanoFAST tag only 98 amino acid residues long was developed [71].

FAST has also been applied to single-molecule localization microscopy in living and fixed cells. Due to the exchangeability and activation of fluorescence, it is possible to detect fluorogen binding events as bursts of fluorescence [72]. However, the reconstruction of FAST-labeled cell structures in living cells was quite tricky. The fluorogen was not photostable and, at low concentrations, quickly photobleached under high laser power illumination. As a remedy, a special buffer with oxygen scavengers was used in fixed cells, prolonging the acquisition. However, it took about $1 \mathrm{~h}$ and 90,000 frames to reconstruct the microtubules due to low localization density. Despite the dubious applicability of FAST in classical implementations of single-molecule localization microscopy, the exchangeability of the fluorogen provides local fluctuations in the fluorescence intensity. This property made it possible to perform super-resolution radial fluctuations (SRRF) analysis [73].

A short time after the appearance of the labeling system based on FAST, a similar system called $\mathrm{DiB}$ (dye in Blc) appeared with a fluorogen-activating protein based on bacterial lipocalin Blc and fluorogens-analogs of the GFP chromophore (Figure 3) [74]. The development of DiB tags was guided by in silico mutagenesis and molecular docking of the GFP chromophore. Then, the best mutants (further: DiB1, DiB2, and DiB3) were screened in vitro against a fluorogens library. One of the best-performing fluorogens was M739 with the distinctive feature that it contains a fluoroborate group which blocks photoisomerization, therefore increasing the fluorescence quantum yield. The dissociation constants of DiBs complexes with M739 ranged from 0.1 to $9 \mu \mathrm{M}$. In terms of photostability, they are superior to conventional fluorescent proteins and can be used in single-molecule localization microscopy, showing a high density and stability of the number of localizations. This makes it possible to reconstruct the labeled structures in a reasonably short time in high quality. The photostability of the DiBs is also beneficial for light-intensive super-resolution approaches, such as stimulated emission depletion, where DiBs outperformed fluorescent proteins. Later, a red fluorogen compatible with DiBs was published, which was also applicable for localization microscopy in living cells [75]. In addition, a self-assembling 
split system was created based on the DiB2 scaffold, which, like the full-length DiBs, showed high performance in super-resolution microscopy, and the stability of localization density turned out to be even higher than that of the full-length DiB2 [76].

Crystallization of $\mathrm{DiB1}$ with the fluorogen M739 underpinned rational mutagenesis of all three DiBs, thereby improved variants were created [77]. The DiB3/F74V and DiB3/F53L/F74L/L129M mutants in complex with fluorogen M739 have an emission peak of about $540 \mathrm{~nm}$, while the emission of DiB3/F53L is red-shifted up to $562 \mathrm{~nm}$. The differences in spectra were sufficient for simultaneous two-channel single-molecule localization microscopy of structures labeled by different DiB3 mutants. Furthermore, improved DiB variants exhibit increased stability of localization density, single-molecule brightness, and localization precision. In addition, a temporal resolution of about one super-resolved reconstruction per minute was demonstrated.

Recent advances in computational structural biology allowed for the 69 design of $\beta$-barrel-type proteins that bind fluorogens and activate their fluorescence [78]. The dissociation constants of these de novo designed mFAP1 and mFAP2 proteins and the 3,5difluoro-4-hydroxybenzylidene imidazolinone (DFHBI) fluorogen were 0.18 and $0.56 \mu \mathrm{M}$, respectively. Unfortunately, the fluorescence quantum yield of complexes with the chromophore DFHBI (Figure 3) was only about $2 \%$, and in terms of relative brightness, these tags were $\approx 35$ times dimmer than the fluorescent protein EGFP. Despite this, the de novo $\beta$-barrel has become a versatile platform for introducing biosensory functions into it [79]. Thus, a split of mFAP was created to detect the association and dissociation of proteins. It was shown that it is possible to design improved variants of mFAPs, one of which, mFAP10, is only two times dimmer than EGFP, reaching a fluorescence quantum yield of about $23 \%$ in complex with the 3,5-difluoro-4-hydroxybenzylidene-2,2,2-trifluoroethyl imidazolinone (DFHBI-1T) fluorogen (Figure 3). Biosensors for $\mathrm{pH}$ and calcium levels were also designed. Overall, the mFAP platform showcased the current level of computational structural biology, which no doubt will be one of the pillars of the development of novel protein tags.

The most recently developed system for chemogenetic labeling of proteins with exchangeable probes is based on dimeric transcription factors LmrR and RamR [80]. The modified transcription factors reversibly bind commercially available DFHBI and BODIPY chromophores (Figure 3). Dissociation constants ranging from submicromoles to several micromoles allow for simple chromophore washing and staining protocol. The system, dubbed chemogenetic tags with probe exchange (CTPEs), is well suited for in vivo labeling of bacterial proteins. To reduce the affinity of transcription factors to DNA, point mutations were introduced into the DNA binding interface. Interestingly, within one homodimer LamR molecule, there are two pockets for binding chromophore in contrast to RamR, in which there is only one pocket in the homodimer.

Overall, labeling systems with fluorogen-activating proteins has gained some traction in the community. The key advantages of FAPs are the ability to carry out prolonged acquisition or alternate staining in living cells, which cannot be done using conventional fluorescent proteins, irreversibly anchored to the labeled structure. In addition, some systems perform very well in super-resolution microscopy in both fixed and living cells (Table 1).

More than ten years have elapsed since the development of an antibody for a molecular rotor dye before this principle was first used for the fluorescent labeling of proteins. Today, the class of FAP tagging systems is growing quite rapidly, and different niches have emerged in it. Notably, Y-FAST-related labels are well suited for protein labeling in living cells and even whole organisms using wide-field microscopy. It is also possible to carry out simultaneous two-color labeling with orthogonal FAST variants. The very low nonspecific chromophore signal in the membranes and the high fluorescence enhancement upon binding make FAST an excellent fluorescent labeling system. The labeling system based on bacterial lipocalin from the DiB family performs well in wide-field microscopy but is inferior to the system based on Y-FAST because of a higher signal of chromophores 
associated with cell membranes. However, in localization nanoscopy, DiBs have no equal. High stability of localization density in combination with high brightness at the level of single molecules makes DiBs an ideal marker for super-resolution in living cells, including time-lapse nanoscopy. Despite the relatively active development of fluorogen-activating proteins in recent years, each fluorogen-protein pair has its strengths and weaknesses. Therefore, there is still no universal tagging system that could be used in any conditions for any task.

Table 1. Characteristics of existing labeling systems based on fluorogen-activating proteins.

\begin{tabular}{|c|c|c|c|c|c|}
\hline System & Protein Size, kDa & $\mathrm{K}_{\mathrm{D}, \mu \mathrm{M}}$ & Color & Super-Resolution Implementation & Reference \\
\hline $\mathrm{scFv}$ & $11.2-26.5$ & $0.0012-0.712$ & blue-far red & SMLM, STED & {$[17,51,53,81]$} \\
\hline UnaG & 15.6 & 0.000098 & green & SMLM & {$[59,61]$} \\
\hline Y-FAST & 14.0 & $0.14-16.0$ & blue-far red & SRRF & {$[62,65,73]$} \\
\hline $\mathrm{DiB}$ & 18.1 & $0.1-9.0$ & green-red & SMLM, STED & {$[74,75,77]$} \\
\hline mFAP & 14.0 & $0.045-11.0$ & green & not tested & {$[78,79]$} \\
\hline LmrR/RamR & $15.0-23.0$ & $0.2-10.0$ & green-red & not tested & {$[80]$} \\
\hline
\end{tabular}

\section{Cytoskeleton Labeling}

One of the most spectacular intracellular structures from the point of view of a microscopist is a cytoskeleton. Usually, it consists of three types of fibers-microfilaments, intermediate filaments, and microtubules. Conventional or high-affinity tags are the most widely used for staining the cytoskeleton. However, nearly all of them exhibit low photostability, low labeling density, or could not be used in live-cell microscopy [7]. In addition, a common feature of cytoskeleton fibers is their composition of monomers which polymerize and depolymerize in response to cellular stimuli. Importantly, some high-affinity labels, such as phalloidin-based labels [82], stabilize the polymerized form, disrupting normal cellular functioning $[83,84]$.

As a way to overcome these limitations, the low-affinity transiently interaction labels were introduced $[7,8]$. One example is a Lifeact-a short (just 17 amino acids) fragment of actin filament-binding protein Abp140 from Saccharomyces cerevisiae [14]. Low affinity to F-actin $\left(\mathrm{K}_{\mathrm{D}} \approx 2.2 \mu \mathrm{M}\right)$ results in a rapid exchange of probes (within $\left.0.4 \mathrm{~s}\right)$ [14]. Additionally, Lifeact was used as an actin-labeling probe in the labeling technique named IRIS (image reconstruction by integrating exchangeable single-molecule localization) [8]. In IRIS, transient interaction of diverse fluorescently-labeled proteins and their protein partners within the fixed cell sample resulted in staining of target structures. In a manner similar to the single-molecule speckle microscopy [32], binding events visible at low concentration of fluorescently-labeled protein probes were registered as fluorescent speckles and were used to reconstruct super-resolution images. Using IRIS, Kiuchi et al., convincingly demonstrated improved labeling density, in comparison with conventional immunostaining. Notably, Lifeact could be used for high-density super-resolution imaging in both fixed [8] and living cells $[8,85,86]$.

However, the Lifeact application for actin imaging has several limitations and drawbacks. For example, the Lifeact labeling of filopodia or cofilin-bound actin may be imperfect or fail completely $[22,87,88]$. In addition, Lifeact exhibits a 10-fold higher affinity to G-actin, leading to background cytosolic actin labeling [14]. Nonetheless, the Lifeact-based imaging of actin is comparable or slightly better than ASTORM (direct STORM) with conventional phalloidin staining [82]. The list of actin-binding probes with low affinity includes Utr261 and F-tractin. The first one is the first 261 amino acid residues of utrophin-the filamentcrosslinking protein [89], which binds to F-actin without stabilizing it [90]. With the $\mathrm{K}_{\mathrm{D}}$ in a micromolar range (18.6 $\mu \mathrm{M}$ [90]), Utr261 can be used for live-cell F-actin imaging [89]. Additionally, the truncated form of Utr261-Utr230 - seems to be a unique live-cell probe, which can label short actin filaments in mammalian nuclei [91]. According to a comparative study of Belin et al., another probe-F-tractin (residues 10-52 of rat inositol 1,4,5-triphosphate- 
3-kinase A [92]) efficiently stains a broad range of actin structures [22]. In addition, the F-tractin probe has the highest exchange rate among all actin tags [22].

Other cytoskeleton structures also could be labeled in a transient manner. For example, microtubule-associated proteins MAP4 and MAP7 interact with microtubules with $\mathrm{K}_{\mathrm{D}} \approx 0.3 \mu \mathrm{M}$ [93] and $0.47 \mu \mathrm{M}$ [94], respectively. MAPs, as well as microtubule plus-end-tracking protein CLIP-170 [95] and tau protein [96], may be used for microtubule labeling $[8,86,94,97]$. Similarly, intermediate filaments may be labeled with plectin-1 [98]. Of particular note is the motor-PAINT method, based both on PAINT and single-molecule particle tracking [99]. Motor-PAINT utilized the ability of different kinesins to bind to differently oriented microtubules: Kinesin-1 selectively binds to minus-end-oriented microtubules, while Kinesin-3 prefers microtubules that are mostly plus-end-out-oriented. With this technique, one could reveal the orientation of microtubules [100].

\section{Imaging by Peptide-Peptide Interactions}

All the aforementioned methods have limitations in their applicability. Some may only be used in fixed cells, while others require specific probes for different targets. One could envision a universal label, suitable for a multitude of targets and compatible with different microscopy techniques. One of the contenders for the role of a universal labeling agent is $\mathrm{K} / \mathrm{E}$-coils. These are short artificial $\alpha$-helices, which were developed by Chao et al. [101]. Typically, K/E-coils consist of three to five repeating heptads enriched with lysine (K-coils) or glutamate (E-coils) amino acid residues. The heterodimerization of K/E-coils leads to the coiled-coil formation (Figure 4A) and could be fine-tuned in the micromolar-nanomolar range depending on the number of heptad repeats and the amino acid sequence of each heptad (for example, the presence of Ile or Val at the so-called a position of a coiledcoil) [102]. While homodimerization is possible, different charges of K/E-coils determine the predominance of heterodimerization over homodimerization.

Originally, K/E-coils were used in affinity chromatography and biosensor applications [103]. Later, K/E-coils and other coiled-coil-forming peptides became well-known dimerization agents for protein labeling. Therefore, Yano et al., used K/E-coils of 3-4 heptad length ((KIAALKE) $)_{3 / 4}$ for K-coils and (EIAALEK) $)_{3 / 4}$ for E-coils) for transient labeling of surface-exposed receptors of living cells [104]. E-coil was attached to an extracellular terminus of various receptors in this work, while K-coil-conjugate with chemical dye was added to the medium. Others used synthetic coiled-coils called SYNZIPs [105,106], but the general principle remained the same [107]. The listed methods demonstrated the highly specific labeling of different proteins in living cells. However, all of the proteins were transmembrane with extracellular parts, and none of the intracellular proteins was labeled.

The first implementation of K/E-coils for labeling proteins inside the cells with different kinds of microscopies, including localization microscopy, was a KECs (K/E-coils) approach [21]. One coil was fused to a target protein, while the other carried fluorescent protein. Thus, the whole system was fully genetically encoded (Figure 4B). Several different compartments were labeled using a set of $\mathrm{K} / \mathrm{E}$-coils combinations with varying affinity (membrane proteins caveolin-1 and clathrin, actin, myosin, vimentin, histone $\mathrm{H} 2 \mathrm{~B}$, and others). In addition, in partial illumination conditions, such as in TIRF, the photostability of labeling was significantly increased compared to covalent labeling. This feature allowed long-term imaging both in wide-field and localization microscopy conditions. Additionally, the authors demonstrated the usability of KECs for imaging de novo synthesized proteins. Nevertheless, noticeable background in the cytoplasm derived from unbound labels should be mentioned as a disadvantage of KECs labeling.

Later, Eklund et al., combined the imaging principle of DNA-PAINT and K/E-coils as the labeling agent in the peptide-PAINT method [108]. They used two pairs of K/E-coils with $\mathrm{K}_{\mathrm{D}}$ of $1.7 \mu \mathrm{M}$ and $81 \mathrm{nM}$. While one coil was bound to target protein via antibodies, the second was conjugated with Cy3B and freely diffused in the medium (Figure 4C). However, despite the significant decrease in both $\boldsymbol{\tau}_{\mathrm{d}}$ and $\boldsymbol{\tau}_{\mathrm{b}}$ comparing to classical DNA-PAINT, 
it still required antibodies for protein tagging. Therefore, peptide-PAINT is a relatively expensive method that could be used in fixed cells only.

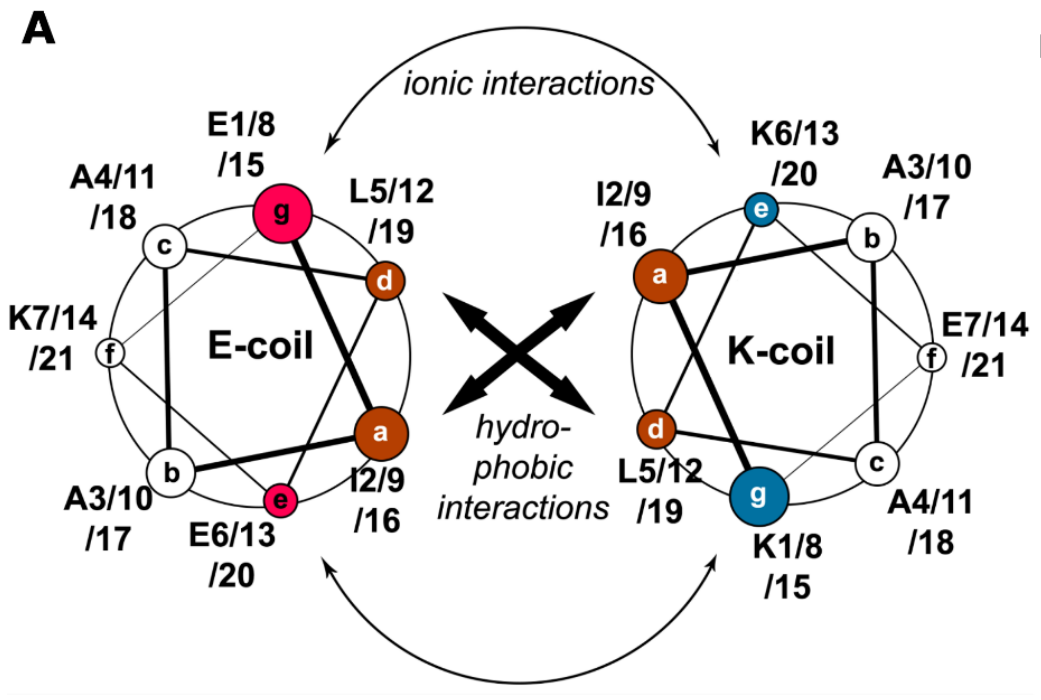

B

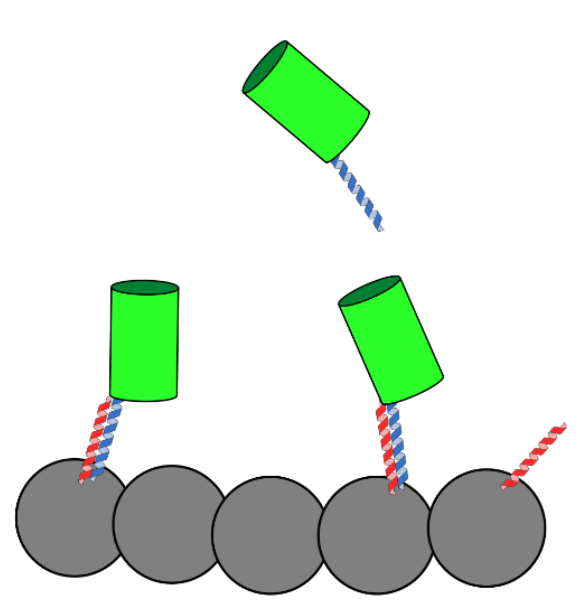

C

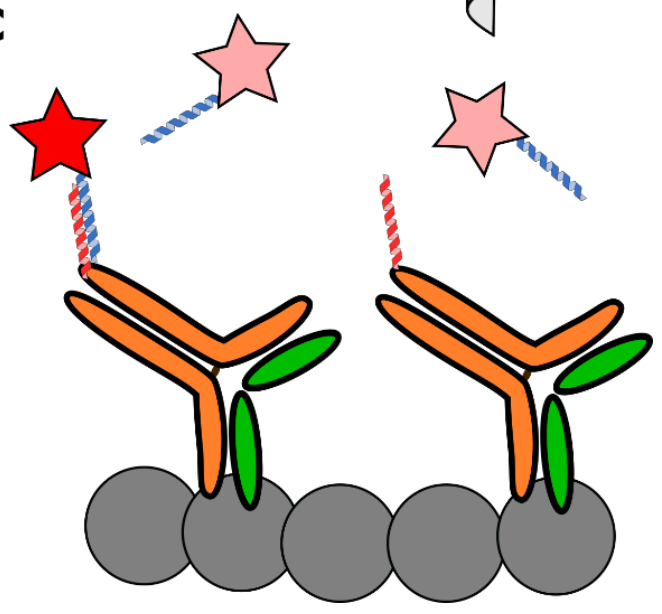

E-coil K-coil

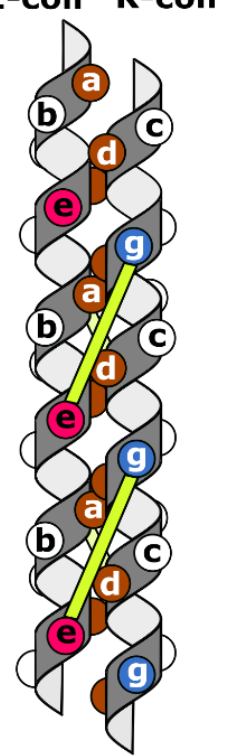

$\sqrt{2}+x^{2}$ 
aged structures in living yeast cells. However, to achieve PAINT conditions, the concentration of labels was very low, resulting in a small number of localizations.

In our opinion, the use of interacting peptides is a very promising labeling approach that may be used both with fixed and living cells. The extension of KECs for multitarget imaging can be achieved, in principle, with orthogonal variants of K/E-coils. The feasibility of multitarget labeling with orthogonal coils was demonstrated with SYNZIP coils labeling of extracellular membrane proteins [107]. Multiple orthogonal coiled-coils were recently reported [111-113] and used, for example, in drug delivery systems [114], paving the way to future implementations of multitarget labeling.

\section{Exchange-STED}

Another super-resolution technique that may use the advantages of exchangeable labeling is STED microscopy [115]. In the STED microscope, in addition to the excitation laser beam, a red-shifted high-power STED-laser beam coincides with the excitation laser at the focal plane and depletes fluorescence in the outer region of the PSF by stimulated emission. In the simplest scenario, the STED-laser is engineered to acquire a donutshaped structure at the focal plane. The stimulated emission of the fluorophores in the outer rim of the donut shrinks the effective PSF to the area near its center, increasing the resolution [43,115]. Theoretically, with the increase of STED-laser intensity, one can reach extremely high resolution [116]. However, in practice, STED-laser power is limited by photodamage of a sample and photostability of labeling.

Recent papers demonstrated the usability of transient labels for STED [74,117-119]. In contrast with nanomolar concentrations for PAINT labels, much higher concentrations $(\approx 100 \mathrm{nM}-1 \mu \mathrm{M})$ were used for exchange-based STED [117]. In addition, the optimal affinity required for fast replacement of the fluorophores in exchange-based STED lies in the range of $1-10 \mu \mathrm{M}$ [117]. The set of tags that satisfy these requirements include Lifeact $\left(\mathrm{K}_{\mathrm{D}}=2.2 \mu \mathrm{M}\right.$ [14] $)$ and SiR-Hoechst $\left(\mathrm{K}_{\mathrm{D}}=8.4 \mu \mathrm{M}\right.$ [120] $)$ for staining of actin filaments and DNA, respectively [117]. Importantly, the dynamics of target structures in living cells could be registered with STED-enabled high-resolution with such exchangeable probes [119]. Similarly, rapid exchange of fluorogens in the protein-PAINT method provides an improvement in photostability in STED imaging [74].

Another way of performing STED imaging with exchangeable probes is using the Exchange-PAINT [37] (a DNA-PAINT [30] variant for multitarget imaging) labeling technique. Despite several attempts to combine DNA-PAINT with STED [121,122], only Spahn et al., demonstrated improved labeling photostability [118]. In this work, they tuned docking and imager strands to achieve a fast exchange rate. Multitarget (2-4 protein structures) labeling was also demonstrated, achieved by either repeated imaging-washing cycles and orthogonal docking-imager pairs [121,122], or simultaneously staining all targets with orthogonal pairs of strands [118]. Similarly, but using distinct probes for different structures, the dual-color STED in living cells was performed [117].

\section{Conclusions and Perspectives}

Transient labeling, which started with just a few low-affinity tags, has now developed into a pleiad of methods compatible with most modern modalities of fluorescence microscopy (Table 2). Today, transient labels can be used to stain nearly all biomolecules of living cells: proteins, lipids, and DNA.

Importantly, transient labeling is intrinsically well-suited for multiplex high-content imaging due to an easy sequential staining and washing. Notably, not only eukaryotic cells but also bacterial cells were successfully imaged with PAINT [123]. Existing low-affinity labeling methods are compatible with different microscopy setups, ranging from common wide-field and TIRF microscopy to lattice light-sheet microscopy [124]. 
Table 2. Summary of the methods presented in this review.

\begin{tabular}{|c|c|c|c|c|c|}
\hline Method & Target & $\begin{array}{l}\text { Super-Resolution } \\
\text { Implementation }\end{array}$ & $\begin{array}{c}\text { Fixed/Live-Cell } \\
\text { Imaging }\end{array}$ & $\begin{array}{l}\text { Genetically } \\
\text { Encoded? }\end{array}$ & Reference \\
\hline PAINT & Membranes & SMLM, STED & Both & No & {$[26,117]$} \\
\hline DNA-PAINT & DNA-origami, proteins & SMLM, STED, SOFI & Fixed & No & {$[30,34,44,118]$} \\
\hline uPAINT & Proteins & SMLM & Live-cell & No & [31] \\
\hline RNA-aptamers & RNA & SMLM & Both & Partially ${ }^{1}$ & [48] \\
\hline FAPs & Proteins & SMLM, STED, SRRF & Both & Partially ${ }^{1}$ & {$[17,61,73,77]$} \\
\hline IRIS $^{2}$ & Proteins & SMLM, STED & Both & Both ${ }^{3}$ & {$[8,86,117]$} \\
\hline $\mathrm{KECs}^{4}$ & Proteins & SMLM & Both & Yes & {$[21,109]$} \\
\hline Peptide-PAINT & DNA-origami, proteins & SMLM & Fixed & No & [108] \\
\hline
\end{tabular}

${ }^{1}$ A combination of genetically encoded part with organic fluorogens added externally; ${ }^{2}$ includes other methods, based on probe that transiently interacts with a specific target protein; ${ }^{3}$ could be used either with organic dyes or fluorescent proteins; ${ }^{4}$ and LIVE-PAINT.

Since the demonstration of the effectiveness of transient labels for most cellular targets has already been shown, significant progress can be expected in the quality and color palette of these molecular tools. A promising direction is a development of SiR-actin/SiRtubulin-like fluorogenic dyes [19] but with low-affinity binding. This would pave the way for tracking native cellular proteins with minimal disturbance of target protein functioning due to transient interactions with a dye and absence of a bulky protein tag.

Above all, the versatility concerning target molecules should be improved. Studies need to focus on developing a more common way of staining protein structures, lipid membranes, or nucleic acids with the same or a slightly different approach. In addition, the transient tags with improved and higher signal-to-noise ratio are needed, in order to follow the natural dynamics of cellular structures with minimal photodamage.

Author Contributions: M.M.P., A.S.G., K.A.L. and A.S.M. were involved in writing, review and editing of this article. Figures were created by M.M.P. and A.S.G. and approved by all authors. All authors have read and agreed to the published version of the manuscript.

Funding: The work was supported by a grant from the Ministry of Science and Higher Education of the Russian Federation (agreement No. 075-15-2020-773).

Conflicts of Interest: The authors declare no conflict of interest.

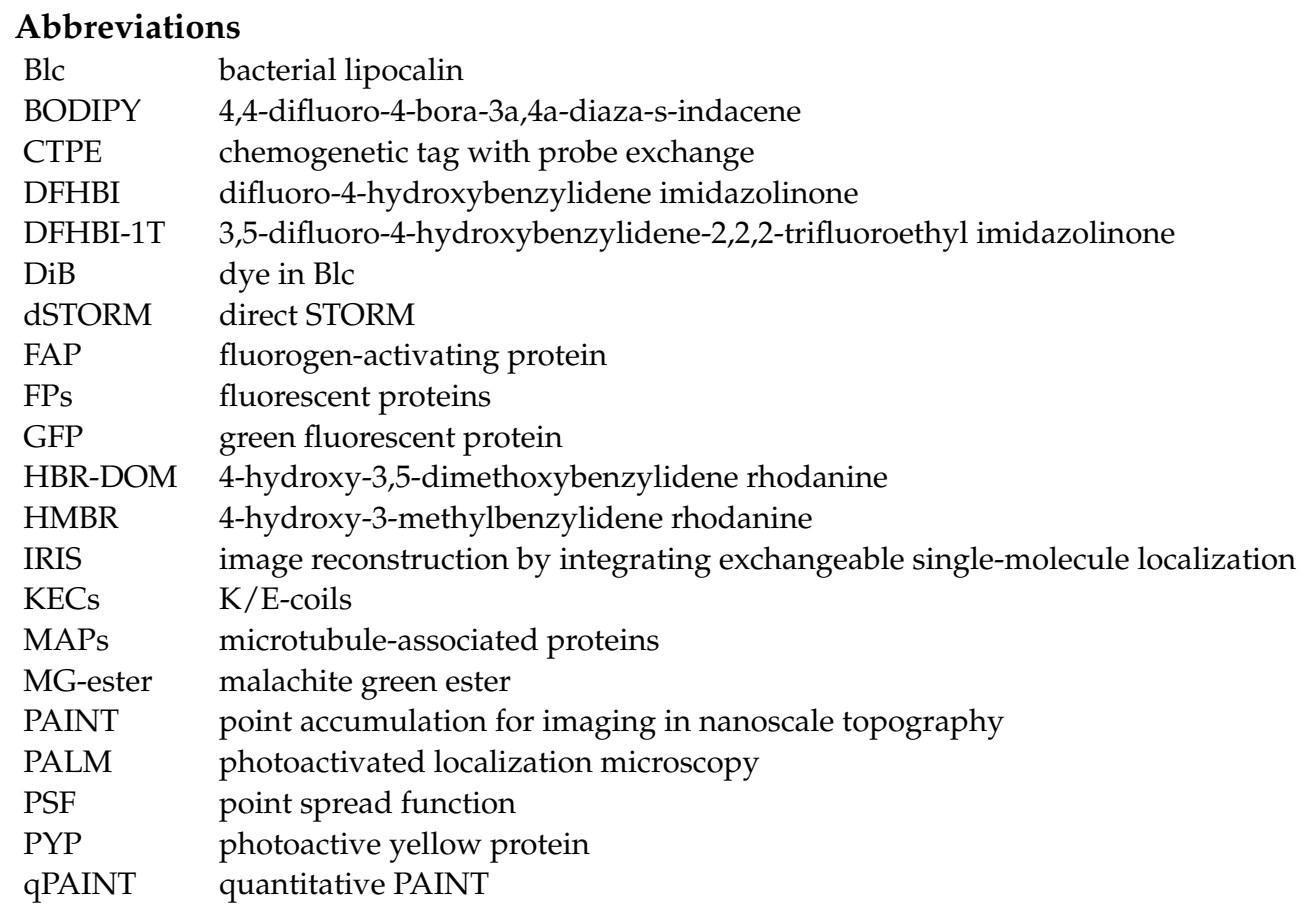




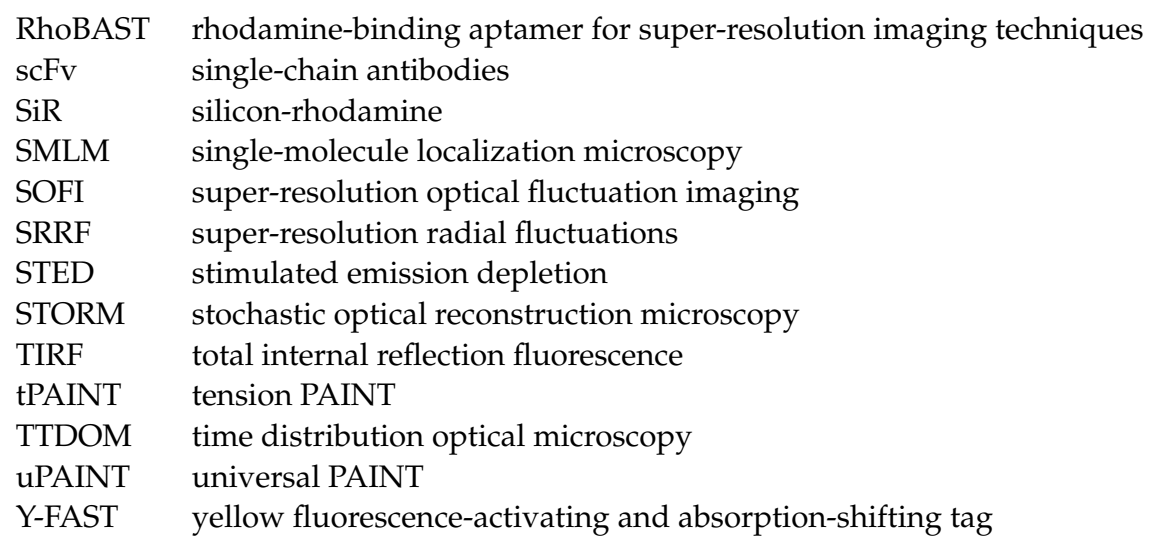

\section{References}

1. Sahl, S.J.; Hell, S.W.; Jakobs, S. Fluorescence nanoscopy in cell biology. Nat. Rev. Mol. Cell Biol. 2017, 18, 685-701. [CrossRef] [PubMed]

2. Tsien, R.Y. The green fluorescent protein. Annu. Rev. Biochem. 1998, 67, 509-544. [CrossRef] [PubMed]

3. Mishin, A.S.; Belousov, V.V.; Solntsev, K.M.; Lukyanov, K.A. Novel uses of fluorescent proteins. Curr. Opin. Chem. Biol. 2015, 27, 1-9. [CrossRef]

4. Hoelzel, C.A.; Zhang, X. Visualizing and manipulating biological processes by using HaloTag and SNAP-Tag technologies. ChemBioChem 2020, 21, 1935-1946. [CrossRef] [PubMed]

5. Xu, J.; Ma, H.; Liu, Y. Stochastic Optical Reconstruction Microscopy (STORM). Curr. Protoc. Cytom. 2017, 81, 12.46.1-12.46.27. [CrossRef] [PubMed]

6. Olivier, N.; Keller, D.; Rajan, V.S.; Gönczy, P.; Manley, S. Simple buffers for 3D STORM microscopy. Biomed. Opt. Express 2013, 4, 885-899. [CrossRef] [PubMed]

7. Sauer, M. Localization microscopy coming of age: From concepts to biological impact. J. Cell Sci. 2013, 126, 3505-3513. [CrossRef] [PubMed]

8. Kiuchi, T.; Higuchi, M.; Takamura, A.; Maruoka, M.; Watanabe, N. Multitarget super-resolution microscopy with high-density labeling by exchangeable probes. Nat. Methods 2015, 12, 743-746. [CrossRef] [PubMed]

9. Gavrikov, A.S.; Baranov, M.S.; Mishin, A.S. Live-cell nanoscopy with spontaneous blinking of conventional green fluorescent proteins. Biochem. Biophys. Res. Commun. 2020, 522, 852-854. [CrossRef]

10. Paez-Segala, M.G.; Sun, M.G.; Shtengel, G.; Viswanathan, S.; Baird, M.A.; Macklin, J.J.; Patel, R.; Allen, J.R.; Howe, E.S.; Piszczek, G.; et al. Fixation-resistant photoactivatable fluorescent proteins for CLEM. Nat. Methods 2015, 12, 215-218. [CrossRef] [PubMed]

11. Kabsch, W.; Mannherz, H.G.; Suck, D.; Pai, E.F.; Holmes, K.C. Atomic structure of the actin: DNase I complex. Nature 1990, 347, 37-44. [CrossRef] [PubMed]

12. Orm, M.; Cubitt, A.B.; Kallio, K.; Gross, L.A.; Tsien, R.Y.; Remington, S.J. Crystal structure of the aequorea victoria green fluorescent protein. Science 1996, 273, 1392-1395. [CrossRef] [PubMed]

13. Kanchanawong, P.; Waterman, C.M. Localization-based super-resolution imaging of cellular structures. Methods Mol. Biol. 2013, 1046, 59-84. [PubMed]

14. Riedl, J.; Crevenna, A.H.; Kessenbrock, K.; Yu, J.H.; Neukirchen, D.; Bista, M.; Bradke, F.; Jenne, D.; Holak, T.A.; Werb, Z.; et al. Lifeact: A versatile marker to visualize F-Actin. Nat. Methods 2008, 5, 605-607. [CrossRef] [PubMed]

15. Greenbaum, L.; Rothmann, C.; Lavie, R.; Malik, Z. Green fluorescent protein photobleaching: A model for protein damage by endogenous and exogenous singlet oxygen. Biol. Chem. 2000, 381, 1251-1258. [CrossRef] [PubMed]

16. Pakhomov, A.A.; Martynov, V.I.; Orsa, A.N.; Bondarenko, A.A.; Chertkova, R.V.; Lukyanov, K.A.; Petrenko, A.G.; Deyev, I.E. Fluorescent Protein Dendra2 as a Ratiometric Genetically Encoded pH-Sensor. Biochem. Biophys. Res. Commun. 2017, 493, 1518-1521. [CrossRef] [PubMed]

17. Yan, Q.; Schwartz, S.L.; Maji, S.; Huang, F.; Szent-Gyorgyi, C.; Lidke, D.S.; Lidke, K.A.; Bruchez, M.P. Localization microscopy using noncovalent Fluorogen activation by genetically encoded Fluorogen-activating proteins. ChemPhysChem 2014, 15, 687-695. [CrossRef] [PubMed]

18. Johnson, I.D.; Kang, H.C.; Haugland, R.P. Fluorescent membrane probes incorporating Dipyrrometheneboron Difluoride Fluorophores. Anal. Biochem. 1991, 198, 228-237. [CrossRef]

19. Lukinavičius, G.; Reymond, L.; D’Este, E.; Masharina, A.; Göttfert, F.; Ta, H.; Güther, A.; Fournier, M.; Rizzo, S.; Waldmann, H.; et al. Fluorogenic probes for live-cell imaging of the cytoskeleton. Nat. Methods 2014, 11, 731-733. [CrossRef] [PubMed]

20. Dubois, J.; Le Goff, M.T.; Guéritte-Voegelein, F.; Guénard, D.; Tollon, Y.; Wright, M. Fluorescent and biotinylated analogues of docetaxel: Synthesis and biological evaluation. Bioorg. Med. Chem. 1995, 3, 1357-1368. [CrossRef]

21. Perfilov, M.M.; Gurskaya, N.G.; Serebrovskaya, E.O.; Melnikov, P.A.; Kharitonov, S.L.; Lewis, T.R.; Arshavsky, V.Y.; Baklaushev, V.P.; Mishin, A.S.; Lukyanov, K.A. Highly photostable fluorescent labeling of proteins in live cells using exchangeable coiled coils heterodimerization. Cell. Mol. Life Sci. 2020, 77, 4429-4440. [CrossRef] [PubMed] 
22. Belin, B.J.; Goins, L.M.; Dyche Mullins, R. Comparative analysis of tools for live cell imaging of Actin network architecture. BioArchitecture 2014, 4, 189-202. [CrossRef] [PubMed]

23. Mei, E.; Gao, F.; Hochstrasser, R.M. Controlled bimolecular collisions allow sub-diffraction limited microscopy of lipid vesicles. Phys. Chem. Chem. Phys. 2006, 8, 2077-2082. [CrossRef] [PubMed]

24. Hou, Y.; Bardo, A.M.; Martinez, C.; Higgins, D.A. Characterization of molecular scale environments in polymer films by single molecule spectroscopy. J. Phys. Chem. B 2000, 104, 212-219. [CrossRef]

25. Mei, E.; Hochstrasser, R.M. High-resolution optical imaging from trajectory time distributions. J. Phys. Chem. B 2006, 110, $25101-25107$. [CrossRef] [PubMed]

26. Sharonov, A.; Hochstrasser, R.M. Wide-field Subdiffraction imaging by accumulated binding of diffusing probes. Proc. Natl. Acad. Sci. USA 2006, 103, 18911-18916. [CrossRef]

27. Rust, M.J.; Bates, M.; Zhuang, X. Sub-diffraction-limit imaging by Stochastic Optical Reconstruction Microscopy (STORM). Nat. Methods 2006, 3, 793-795. [CrossRef]

28. Hess, S.T.; Girirajan, T.P.K.; Mason, M.D. Ultra-high resolution imaging by fluorescence photoactivation localization microscopy. Biophys. J. 2006, 91, 4258-4272. [CrossRef]

29. Betzig, E.; Patterson, G.H.; Sougrat, R.; Lindwasser, O.W.; Olenych, S.; Bonifacino, J.S.; Davidson, M.W.; Lippincott-Schwartz, J.; Hess, H.F. Imaging intracellular fluorescent proteins at nanometer resolution. Science 2006, 313, 1642-1645. [CrossRef]

30. Jungmann, R.; Steinhauer, C.; Scheible, M.; Kuzyk, A.; Tinnefeld, P.; Simmel, F.C. Single-molecule kinetics and super-resolution microscopy by fluorescence imaging of transient binding on DNA origami. Nano Lett. 2010, 10, 4756-4761. [CrossRef]

31. Giannone, G.; Hosy, E.; Levet, F.; Constals, A.; Schulze, K.; Sobolevsky, A.I.; Rosconi, M.P.; Gouaux, E.; Tampé, R.; Choquet, D.; et al. Dynamic superresolution imaging of endogenous proteins on living cells at ultra-high density. Biophys. J. 2010, 99, 1303-1310. [CrossRef] [PubMed]

32. Watanabe, N.; Mitchison, T.J. Single-molecule speckle analysis of actin filament turnover in lamellipodia. Science 2002, 295, 1083-1086. [CrossRef] [PubMed]

33. Rothemund, P.W.K. Folding DNA to create nanoscale shapes and patterns. Nature 2006, 440, 297-302. [CrossRef] [PubMed]

34. Jungmann, R.; Avendaño, M.S.; Dai, M.; Woehrstein, J.B.; Agasti, S.S.; Feiger, Z.; Rodal, A.; Yin, P. Quantitative super-resolution imaging with qPAINT. Nat. Methods 2016, 13, 439-442. [CrossRef] [PubMed]

35. Iinuma, R.; Ke, Y.; Jungmann, R.; Schlichthaerle, T.; Woehrstein, J.B.; Yin, P. Polyhedra self-assembled from DNA tripods and characterized with 3D DNA-PAINT. Science 2014, 344, 65-69. [CrossRef]

36. Strauss, S.; Nickels, P.C.; Strauss, M.T.; Jimenez Sabinina, V.; Ellenberg, J.; Carter, J.D.; Gupta, S.; Janjic, N.; Jungmann, R. Modified aptamers enable quantitative sub-10-Nm cellular DNA-PAINT imaging. Nat. Methods 2018, 15, 685-688. [CrossRef]

37. Jungmann, R.; Avendaño, M.S.; Woehrstein, J.B.; Dai, M.; Shih, W.M.; Yin, P. Multiplexed 3D Cellular super-resolution imaging with DNA-PAINT and exchange-PAINT. Nat. Methods 2014, 11, 313-318. [CrossRef]

38. Dai, M.; Jungmann, R.; Yin, P. optical imaging of individual biomolecules in densely packed clusters. Nat. Nanotechnol. 2016, 11, 798-807. [CrossRef]

39. Brockman, J.M.; Su, H.; Blanchard, A.T.; Duan, Y.; Meyer, T.; Quach, M.E.; Glazier, R.; Bazrafshan, A.; Bender, R.L.; Kellner, A.V.; et al. Live-cell super-resolved PAINT imaging of piconewton cellular traction forces. Nat. Methods 2020, 17, $1018-1024$. [CrossRef]

40. Dertinger, T.; Colyer, R.; Iyer, G.; Weiss, S.; Enderlein, J. Fast, background-free, 3D super-resolution optical fluctuation imaging (SOFI). Proc. Natl. Acad. Sci. USA 2009, 106, 22287-22292. [CrossRef]

41. Endesfelder, U.; van de Linde, S.; Wolter, S.; Sauer, M.; Heilemann, M. Subdiffraction-resolution fluorescence microscopy of myosin-actin motility. ChemPhysChem 2010, 11, 836-840. [CrossRef]

42. Geissbuehler, S.; Dellagiacoma, C.; Lasser, T. Comparison between SOFI and STORM. Biomed. Opt. Express 2011, 2, 408-420. [CrossRef] [PubMed]

43. Klementieva, N.V.; Zagaynova, E.V.; Lukyanov, K.A.; Mishin, A.S. The principles of super-resolution fluorescence microscopy (Review). Sovrem. Tehnol. Med. 2016, 8, 130-140. [CrossRef]

44. Glogger, M.; Spahn, C.; Enderlein, J.; Heilemann, M. Multi-color, Bleaching-resistant super-resolution optical fluctuation imaging with oligonucleotide-based exchangeable fluorophores. Angew. Chem. Weinheim Bergstr. Ger. 2021, 133, 6380-6383. [CrossRef]

45. Sharonov, A.; Hochstrasser, R.M. Single-molecule imaging of the association of the cell-penetrating peptide Pep-1 to model membranes. Biochemistry 2007, 46, 7963-7972. [CrossRef]

46. Paige, J.S.; Wu, K.Y.; Jaffrey, S.R. RNA mimics of green fluorescent protein. Science 2011, 333, 642-646. [CrossRef] [PubMed]

47. Braselmann, E.; Rathbun, C.; Richards, E.M.; Palmer, A.E. Illuminating RNA biology: Tools for imaging RNA in live mammalian cells. Cell Chem. Biol. 2020, 27, 891-903. [CrossRef]

48. Sunbul, M.; Lackner, J.; Martin, A.; Englert, D.; Hacene, B.; Grün, F.; Nienhaus, K.; Nienhaus, G.U.; Jäschke, A. Super-resolution RNA imaging using a rhodamine-binding aptamer with fast exchange kinetics. Nat. Biotechnol. 2021. [CrossRef]

49. Kung, C.E.; Reed, J.K. Fluorescent molecular rotors: A new class of probes for tubulin structure and assembly. Biochemistry 1989, 28, 6678-6686. [CrossRef]

50. Iwaki, T.; Torigoe, C.; Noji, M.; Nakanishi, M. Antibodies for fluorescent molecular rotors. Biochemistry 1993, $32,7589-7592$. [CrossRef] 
51. Szent-Gyorgyi, C.; Schmidt, B.F.; Creeger, Y.; Fisher, G.W.; Zakel, K.L.; Adler, S.; Fitzpatrick, J.A.J.; Woolford, C.A.; Yan, Q.; Vasilev, K.V.; et al. Fluorogen-activating single-chain antibodies for imaging cell surface proteins. Nat. Biotechnol. 2008, 26, 235-240. [CrossRef] [PubMed]

52. Ozhalici-Unal, H.; Pow, C.L.; Marks, S.A.; Jesper, L.D.; Silva, G.L.; Shank, N.I.; Jones, E.W.; Burnette, J.M., 3rd; Berget, P.B.; Armitage, B.A. A rainbow of fluoromodules: A promiscuous $\mathrm{scFv}$ protein binds to and activates a diverse set of fluorogenic cyanine dyes. J. Am. Chem. Soc. 2008, 130, 12620-12621.

53. Zanotti, K.J.; Silva, G.L.; Creeger, Y.; Robertson, K.L.; Waggoner, A.S.; Berget, P.B.; Armitage, B.A. Blue fluorescent dye-protein complexes based on fluorogenic cyanine dyes and single chain antibody fragments. Org. Biomol. Chem. 2011, 9, 1012-1020. [CrossRef]

54. He, J.; Wang, Y.; Missinato, M.A.; Onuoha, E.; Perkins, L.A.; Watkins, S.C.; St Croix, C.M.; Tsang, M.; Bruchez, M.P. A genetically targetable near-infrared photosensitizer. Nat. Methods 2016, 13, 263-268. [CrossRef] [PubMed]

55. Perkins, L.A.; Yan, Q.; Schmidt, B.F.; Kolodieznyi, D.; Saurabh, S.; Larsen, M.B.; Watkins, S.C.; Kremer, L.; Bruchez, M.P. Genetically targeted ratiometric and activated ph indicator complexes (TRApHIC) for receptor trafficking. Biochemistry 2018, 57, 861-871. [CrossRef]

56. Wang, Y.; Ballou, B.; Schmidt, B.F.; Andreko, S.; St Croix, C.M.; Watkins, S.C.; Bruchez, M.P. Affibody-Targeted fluorogen activating protein for in vivo tumor imaging. Chem. Commun. 2017, 53, 2001-2004. [CrossRef]

57. Wang, Y.; Telmer, C.A.; Schmidt, B.F.; Franke, J.D.; Ort, S.; Arndt-Jovin, D.J.; Bruchez, M.P. Fluorogen activating protein-affibody probes: Modular, no-wash measurement of epidermal growth factor receptors. Bioconjug. Chem. 2015, 26, 137-144. [CrossRef]

58. Lyakhov, I.; Zielinski, R.; Kuban, M.; Kramer-Marek, G.; Fisher, R.; Chertov, O.; Bindu, L.; Capala, J. HER2- and EGFR-Specific Affiprobes: Novel recombinant optical probes for cell imaging. ChemBioChem 2010, 11, 345-350. [CrossRef]

59. Kumagai, A.; Ando, R.; Miyatake, H.; Greimel, P.; Kobayashi, T.; Hirabayashi, Y.; Shimogori, T.; Miyawaki, A. A bilirubin-inducible fluorescent protein from eel muscle. Cell 2013, 153, 1602-1611. [CrossRef] [PubMed]

60. Hayashi, S.; Toda, Y. A novel fluorescent protein purified from eel muscle. Fish. Sci. 2009, 75, 1461-1469. [CrossRef]

61. Kwon, J.; Park, J.-S.; Kang, M.; Choi, S.; Park, J.; Kim, G.T.; Lee, C.; Cha, S.; Rhee, H.-W.; Shim, S.-H. Bright ligand-activatable fluorescent protein for high-quality multicolor live-cell super-resolution microscopy. Nat. Commun. 2020, 11, 273. [CrossRef] [PubMed]

62. Plamont, M.-A.; Billon-Denis, E.; Maurin, S.; Gauron, C.; Pimenta, F.M.; Specht, C.G.; Shi, J.; Quérard, J.; Pan, B.; Rossignol, J.; et al. Small fluorescence-activating and absorption-shifting tag for tunable protein imaging in vivo. Proc. Natl. Acad. Sci. USA 2016, 113, 497-502. [CrossRef] [PubMed]

63. Tebo, A.G.; Pimenta, F.M.; Zhang, Y.; Gautier, A. Improved chemical-genetic fluorescent markers for live cell microscopy. Biochemistry 2018, 57, 5648-5653. [CrossRef] [PubMed]

64. Li, C.; Plamont, M.-A.; Sladitschek, H.L.; Rodrigues, V.; Aujard, I.; Neveu, P.; Le Saux, T.; Jullien, L.; Gautier, A. Dynamic multicolor protein labeling in living cells. Chem. Sci. 2017, 8, 5598-5605. [CrossRef]

65. Povarova, N.V.; Zaitseva, S.O.; Baleeva, N.S.; Smirnov, A.Y.; Myasnyanko, I.N.; Zagudaylova, M.B.; Bozhanova, N.G.; Gorbachev, D.A.; Malyshevskaya, K.K.; Gavrikov, A.S.; et al. Red-shifted substrates for FAST Fluorogen-activating protein based on the GFP-like chromophores. Chemistry 2019, 25, 9592-9596. [CrossRef]

66. Myasnyanko, I.N.; Gavrikov, A.S.; Zaitseva, S.O.; Smirnov, A.Y.; Zaitseva, E.R.; Sokolov, A.I.; Malyshevskaya, K.K.; Baleeva, N.S.; Mishin, A.S.; Baranov, M.S. Color tuning of fluorogens for FAST Fluorogen-activating protein. Chemistry 2021, 27, 3986-3990. [CrossRef] [PubMed]

67. Li, C.; Tebo, A.G.; Thauvin, M.; Plamont, M.-A.; Volovitch, M.; Morin, X.; Vriz, S.; Gautier, A. A far-red emitting fluorescent chemogenetic reporter for in vivo molecular imaging. Angew. Chem. Int. Ed. Engl. 2020, 59, 17917-17923. [CrossRef] [PubMed]

68. Tebo, A.G.; Gautier, A. A split fluorescent reporter with rapid and reversible complementation. Nat. Commun. 2019, 10, 2822. [CrossRef]

69. Tebo, A.G.; Moeyaert, B.; Thauvin, M.; Carlon-Andres, I.; Böken, D.; Volovitch, M.; Padilla-Parra, S.; Dedecker, P.; Vriz, S.; Gautier, A. Orthogonal fluorescent chemogenetic reporters for multicolor imaging. Nat. Chem. Biol. 2021, 17, 30-38. [CrossRef] [PubMed]

70. Benaissa, H.; Ounoughi, K.; Aujard, I.; Fischer, E.; Goïame, R.; Nguyen, J.; Tebo, A.G.; Li, C.; Le Saux, T.; Danglot, L.; et al. Engineering of a fluorescent chemogenetic reporter with tunable color for advanced live-cell imaging. bioRxiv 2021. [CrossRef]

71. Mineev, K.S.; Goncharuk, S.A.; Goncharuk, M.V.; Povarova, N.V.; Sokolov, A.I.; Baleeva, N.S.; Smirnov, A.Y.; Myasnyanko, I.N.; Ruchkin, D.A.; Bukhdruker, S.; et al. NanoFAST: Structure-Based design of a small fluorogen-activating protein with only 98 amino acids. Chem. Sci. 2021, 12, 6719-6725. [CrossRef] [PubMed]

72. Smith, E.M.; Gautier, A.; Puchner, E.M. Single-Molecule localization microscopy with the fluorescence-activating and absorptionshifting tag (FAST) System. ACS Chem. Biol. 2019, 14, 1115-1120. [CrossRef]

73. Venkatachalapathy, M.; Belapurkar, V.; Jose, M.; Gautier, A.; Nair, D. Live cell super resolution imaging by radial fluctuations using fluorogen binding tags. Nanoscale 2019, 11, 3626-3632. [CrossRef] [PubMed]

74. Bozhanova, N.G.; Baranov, M.S.; Klementieva, N.V.; Sarkisyan, K.S.; Gavrikov, A.S.; Yampolsky, I.V.; Zagaynova, E.V.; Lukyanov, S.A.; Lukyanov, K.A.; Mishin, A.S. Protein labeling for live cell fluorescence microscopy with a highly photostable renewable signal. Chem. Sci. 2017, 8, 7138-7142. [CrossRef]

75. Bozhanova, N.G.; Baranov, M.S.; Baleeva, N.S.; Gavrikov, A.S.; Mishin, A.S. Red-shifted aminated derivatives of GFP Chromophore for live-cell protein labeling with lipocalins. Int. J. Mol. Sci. 2018, 19, 3778. [CrossRef] 
76. Bozhanova, N.G.; Gavrikov, A.S.; Mishin, A.S.; Meiler, J. DiB-Splits: Nature-guided design of a novel fluorescent labeling split system. Sci. Rep. 2020, 10, 11049. [CrossRef]

77. Muslinkina, L.; Gavrikov, A.S.; Bozhanova, N.G.; Mishin, A.S.; Baranov, M.S.; Meiler, J.; Pletneva, N.V.; Pletnev, V.Z.; Pletnev, S. Structure-based rational design of two enhanced bacterial lipocalin tags for protein-PAINT Super-Resolution Microscopy. ACS Chem. Biol. 2020, 15, 2456-2465. [CrossRef]

78. Dou, J.; Vorobieva, A.A.; Sheffler, W.; Doyle, L.A.; Park, H.; Bick, M.J.; Mao, B.; Foight, G.W.; Lee, M.Y.; Gagnon, L.A.; et al. De novo design of a fluorescence-activating $\beta$-barrel. Nature 2018, 561, 485-491. [CrossRef] [PubMed]

79. Klima, J.C.; Doyle, L.A.; Lee, J.D.; Rappleye, M.; Gagnon, L.A.; Lee, M.Y.; Barros, E.P.; Vorobieva, A.A.; Dou, J.; Bremner, S.; et al. Incorporation of sensing modalities into de novo designed fluorescence-activating proteins. Nat. Commun. 2021, 12, 856 [CrossRef]

80. Lyer, A.; Baranov, M.; Foster, A.J.; Chordia, S.; Roelfes, G.; Vlijm, R.; den Bogaart Geert, V.; Poolman, B. Chemogenetic Tags with probe exchange for live-cell fluorescence microscopy. ACS Chem. Biol. 2021, 16, 891-904.

81. Fitzpatrick, J.A.J.; Yan, Q.; Sieber, J.J.; Dyba, M.; Schwarz, U.; Szent-Gyorgyi, C.; Woolford, C.A.; Berget, P.B.; Waggoner, A.S.; Bruchez, M.P. STED nanoscopy in living cells using fluorogen activating proteins. Bioconjug. Chem. 2009, 20, 1843-1847. [CrossRef] [PubMed]

82. Mazloom-Farsibaf, H.; Farzam, F.; Fazel, M.; Wester, M.J.; Meddens, M.B.M.; Lidke, K.A. Comparing lifeact and phalloidin for super-resolution imaging of actin in fixed cells. PLoS ONE 2021, 16, e246138. [CrossRef] [PubMed]

83. Pospich, S.; Merino, F.; Raunser, S. Structural effects and functional implications of phalloidin and jasplakinolide binding to actin filaments. Structure 2020, 28, 437-449. [CrossRef] [PubMed]

84. Visegrády, B.; Lorinczy, D.; Hild, G.; Somogyi, B.; Nyitrai, M. The effect of phalloidin and jasplakinolide on the flexibility and thermal stability of actin filaments. FEBS Lett. 2004, 565, 163-166. [CrossRef]

85. Ashdown, G.W.; Burn, G.L.; Williamson, D.J.; Pandžić, E.; Peters, R.; Holden, M.; Ewers, H.; Shao, L.; Wiseman, P.W.; Owen, D.M. Live-cell super-resolution reveals F-actin and plasma membrane dynamics at the T Cell Synapse. Biophys. J. 2017, 112, 1703-1713. [CrossRef] [PubMed]

86. Zagaynova, E.V.; Furman, O.E.; Perfilov, M.M.; Klementieva, N.V.; Lukyanov, K.A.; Bozhanova, N.G.; Mishin, A.S. Dendra2Tagged Lifeact and MAP4 as exchangeable probes for single-molecule fluorescence imaging of cytoskeleton in live cells. In Proceedings of the Biophotonics: Photonic Solutions for Better Health Care VI; International Society for Optics and Photonics: Bellingham, WA, USA, 2018; Volume 10685, p. 106850S.

87. Sanders, T.A.; Llagostera, E.; Barna, M. Specialized Filopodia Direct Long-Range Transport of SHH during Vertebrate Tissue Patterning. Nature 2013, 497, 628-632. [CrossRef]

88. Munsie, L.N.; Caron, N.; Desmond, C.R.; Truant, R. Lifeact cannot visualize some forms of stress-induced twisted F-Actin. Nat. Methods 2009, 6, 317. [CrossRef]

89. Burkel, B.M.; von Dassow, G.; Bement, W.M. Versatile Fluorescent probes for actin filaments based on the actin-binding domain of utrophin. Cell Motil. Cytoskeleton 2007, 64, 822-832. [CrossRef]

90. Rybakova, I.N.; Ervasti, J.M. Identification of Spectrin-like Repeats Required for High Affinity Utrophin-Actin Interaction. J. Biol. Chem. 2005, 280, 23018-23023. [CrossRef]

91. Belin, B.J.; Cimini, B.A.; Blackburn, E.H.; Dyche Mullins, R. Visualization of Actin Filaments and Monomers in Somatic Cell Nuclei. Molecular Biol. Cell 2013, 24, 982-994. [CrossRef]

92. Schell, M.J.; Erneux, C.; Irvine, R.F. Inositol 1,4,5-Trisphosphate 3-Kinase A Associates with F-Actin and Dendritic Spines via Its N Terminus. J. Biol. Chem. 2001, 276, 37537-37546. [CrossRef] [PubMed]

93. Tokuraku, K.; Matsushima, K.; Matui, T.; Nakagawa, H.; Katsuki, M.; Majima, R.; Kotani, S. The Number of Repeat Sequences in Microtubule-Associated Protein 4 Affects the Microtubule Surface Properties. J. Biol. Chem. 2003, 278, 29609-29618. [CrossRef] [PubMed]

94. Monroy, B.Y.; Sawyer, D.L.; Ackermann, B.E.; Borden, M.M.; Tan, T.C.; Ori-McKenney, K.M. Competition between microtubuleassociated proteins directs motor transport. Nat. Commun. 2018, 9, 1487. [CrossRef] [PubMed]

95. Akhmanova, A. The microtubule plus-end-tracking protein CLIP-170 Associates with the spermatid manchette and is essential for spermatogenesis. Genes Dev. 2005, 19, 2501-2515. [CrossRef]

96. Guo, T.; Noble, W.; Hanger, D.P. Roles of tau protein in health and disease. Acta Neuropathol. 2017, 133, 665-704. [CrossRef]

97. Hooikaas, P.J.; Martin, M.; Mühlethaler, T.; Kuijntjes, G.-J.; Peeters, C.A.E.; Katrukha, E.A.; Ferrari, L.; Stucchi, R.; Verhagen, D.G.F.; van Riel, W.E.; et al. MAP7 Family Proteins Regulate Kinesin-1 Recruitment and Activation. J. Cell Biol. 2019, 218, 1298-1318. [CrossRef]

98. Hijikata, T.; Nakamura, A.; Isokawa, K.; Imamura, M.; Yuasa, K.; Ishikawa, R.; Kohama, K.; Takeda, S.; Yorifuji, H. Plectin 1 links intermediate filaments to costameric sarcolemma through $\beta$-synemin, $\alpha$-dystrobrevin and actin. J. Cell Sci. 2008, 121, $2062-2074$. [CrossRef]

99. Manley, S.; Gillette, J.M.; Lippincott-Schwartz, J. Single-particle tracking photoactivated localization microscopy for mapping single-molecule dynamics. Methods Enzymol. 2010, 475, 109-120.

100. Tas, R.P.; Chazeau, A.; Cloin, B.M.C.; Lambers, M.L.A.; Hoogenraad, C.C.; Kapitein, L.C. Differentiation between Oppositely Oriented Microtubules Controls Polarized Neuronal Transport. Neuron 2017, 96, 1264-1271. [CrossRef] 
101. Chao, H.; Houston, M.E., Jr.; Grothe, S.; Kay, C.M.; O'Connor-McCourt, M.; Irvin, R.T.; Hodges, R.S. Kinetic Study on the Formation of a de Novo Designed Heterodimeric Coiled-Coil: Use of Surface Plasmon Resonance to Monitor the Association and Dissociation of Polypeptide Chains. Biochemistry 1996, 35, 12175-12185. [CrossRef]

102. Litowski, J.R.; Hodges, R.S. Designing heterodimeric two-stranded alpha-helical coiled-coils. Effects of Hydrophobicity and Alpha-Helical propensity on protein folding, stability, and specificity. J. Biol. Chem. 2002, 277, 37272-37279. [CrossRef]

103. Chao, H.; Bautista, D.L.; Litowski, J.; Irvin, R.T.; Hodges, R.S. Use of a Heterodimeric Coiled-Coil System for Biosensor Application and Affinity Purification. J. Chromatogr. B Biomed. Sci. Appl. 1998, 715, 307-329. [CrossRef]

104. Yano, Y.; Yano, A.; Oishi, S.; Sugimoto, Y.; Tsujimoto, G.; Fujii, N.; Matsuzaki, K. Coiled-Coil Tag-Probe System for Quick Labeling of Membrane Receptors in Living Cells. ACS Chem. Biol. 2008, 3, 341-345. [CrossRef]

105. Reinke, A.W.; Grant, R.A.; Keating, A.E. A Synthetic Coiled-Coil Interactome Provides Heterospecific Modules for Molecular Engineering. J. Am. Chem. Soc. 2010, 132, 6025-6031. [CrossRef] [PubMed]

106. Thompson, K.E.; Bashor, C.J.; Lim, W.A.; Keating, A.E. SYNZIP Protein Interaction Toolbox: In Vitro and in Vivo Specifications of Heterospecific Coiled-Coil Interaction Domains. ACS Synth. Biol. 2012, 1, 118-129. [CrossRef] [PubMed]

107. Zane, H.K.; Doh, J.K.; Enns, C.A.; Beatty, K.E. Versatile Interacting Peptide (VIP) Tags for Labeling Proteins with Bright Chemical Reporters. ChemBioChem 2017, 18, 470-474. [CrossRef] [PubMed]

108. Eklund, A.S.; Ganji, M.; Gavins, G.; Seitz, O.; Jungmann, R. Peptide-PAINT Super-Resolution imaging using transient coiled coil interactions. Nano Lett. 2020, 20, 6732-6737. [CrossRef]

109. Oi, C.; Gidden, Z.; Holyoake, L.; Kantelberg, O.; Mochrie, S.; Horrocks, M.H.; Regan, L. LIVE-PAINT Allows Super-Resolution microscopy inside living cells using reversible peptide-protein interactions. Commun. Biol. 2020, 3, 458. [CrossRef]

110. Pratt, S.E.; Speltz, E.B.; Mochrie, S.G.J.; Regan, L. Designed proteins as novel imaging reagents in living Escherichia coli. ChemBioChem 2016, 17, 1652-1657. [CrossRef]

111. Lebar, T.; Lainšček, D.; Merljak, E.; Aupič, J.; Jerala, R. A tunable orthogonal coiled-coil interaction toolbox for engineering mammalian cells. Nat. Chem. Biol. 2020, 16, 513-519. [CrossRef]

112. Gradišar, H.; Jerala, R. De novo design of orthogonal peptide pairs forming parallel coiled-coil heterodimers. J. Pept. Sci. 2011, 17, 100-106. [CrossRef]

113. Ljubetič, A.; Lapenta, F.; Gradišar, H.; Drobnak, I.; Aupič, J.; Strmšek, Ž.; Lainšček, D.; Hafner-Bratkovič, I.; Majerle, A.; Krivec, N.; et al. Design of coiled-coil protein-origami cages that self-assemble in vitro and in vivo. Nat. Biotechnol. 2017, 35, 1094-1101. [CrossRef] [PubMed]

114. Utterström, J.; Naeimipour, S.; Selegård, R.; Aili, D. Coiled Coil-Based Therapeutics and Drug Delivery Systems. Adv. Drug Deliv. Rev. 2021, 170, 26-43. [CrossRef]

115. Hell, S.W.; Wichmann, J. Breaking the Diffraction Resolution Limit by Stimulated Emission: Stimulated-Emission-Depletion Fluorescence Microscopy. Opt. Lett. 1994, 19, 780. [CrossRef]

116. Harke, B.; Keller, J.; Ullal, C.K.; Westphal, V.; Schönle, A.; Hell, S.W. Resolution Scaling in STED Microscopy. Opt. Express 2008, 16, 4154-4162. [CrossRef]

117. Spahn, C.; Grimm, J.B.; Lavis, L.D.; Lampe, M.; Heilemann, M. Whole-Cell, 3D and Multi-Color STED Imaging with Exchangeable Fluorophores. Nano Lett. 2019, 19, 500-505. [CrossRef] [PubMed]

118. Spahn, C.; Hurter, F.; Glaesmann, M.; Karathanasis, C.; Lampe, M.; Heilemann, M. Protein-Specific, Multicolor and 3D STED Imaging in Cells with DNA-Labeled Antibodies. Angew. Chem. Int. Ed. Engl. 2019, 58, 18835-18838. [CrossRef] [PubMed]

119. Urban, N.T.; Willig, K.I.; Hell, S.W.; Nägerl, U.V. STED Nanoscopy of Actin Dynamics in Synapses Deep inside Living Brain Slices. Biophys. J. 2011, 101, 1277-1284. [CrossRef] [PubMed]

120. Lukinavičius, G.; Blaukopf, C.; Pershagen, E.; Schena, A.; Reymond, L.; Derivery, E.; Gonzalez-Gaitan, M.; D’Este, E.; Hell, S.W.; Gerlich, D.W.; et al. SiR-Hoechst Is a Far-Red DNA Stain for Live-Cell Nanoscopy. Nat. Commun. 2015, 6, 1-7. [CrossRef] [PubMed]

121. Schueder, F.; Strauss, M.T.; Hoerl, D.; Schnitzbauer, J.; Schlichthaerle, T.; Strauss, S.; Yin, P.; Harz, H.; Leonhardt, H.; Jungmann, R. Universal super-resolution multiplexing by DNA Exchange. Angew. Chem. Int. Ed. 2017, 56, 4052-4055. [CrossRef]

122. Beater, S.; Holzmeister, P.; Lalkens, B.; Tinnefeld, P. Simple and Aberration-Free 4color-STED-Multiplexing by Transient Binding. Opt. Express 2015, 23, 8630-8638. [CrossRef] [PubMed]

123. Spahn, C.K.; Glaesmann, M.; Grimm, J.B.; Ayala, A.X.; Lavis, L.D.; Heilemann, M. A Toolbox for Multiplexed Super-Resolution Imaging of the E. Coli Nucleoid and Membrane Using Novel PAINT Labels. Sci. Rep. 2018, 8, 14768. [CrossRef] [PubMed]

124. Legant, W.R.; Shao, L.; Grimm, J.B.; Brown, T.A.; Milkie, D.E.; Avants, B.B.; Lavis, L.D.; Betzig, E. High-Density Three-Dimensional Localization Microscopy across Large Volumes. Nat. Methods 2016, 13, 359-365. [CrossRef] 